\title{
VALVASOR - A COMMON ERROR ABOUT HIS PUBLICATIONS ON CERKNIŠKO JEZERO, SLOVENIA
}

\section{VALVASOR - SPLOŠNA POMOTA GLEDE NJEGOVIH OBJAV O CERKNIŠKEM JEZERU, SLOVENIJA}

TREVOR R. SHAW ${ }^{1}$

${ }^{1}$ Karst Research Institute, ZRC SAZU, Titov trg 2, SI-6230 Postojna, Slovenia, e-mail: izrk@zrc-sazu.si 


\section{Abstract}

UDC: $556.538 * 497.4$ (Cerknica) (091)

\section{Trevor R. Shaw : Valvasor - a common error about his publications on Cerkniško jezero, Slovenia}

Valvasor's first relatively simple explanation for the flooding and draining of the Cerkniško jezero lake, published in 1687, was greatly modified and complicated by 1689 when it appeared both in his book Die Ehre dess Hertzogthums Crain and in a paper in Acta Eruditorum. Modern authors who have not verified their sources have wrongly described the latter as a translation of the 1687 paper instead of recognizing the great change in Valvasor's ideas that it contains.

Key words : karst, intermittent lakes, history, Cerknica, J.W. Valvasor.

Izvleček:

UDK: 556.538*497.4 (Cerknica) (091)

\section{Trevor R. Shaw: Valvasor - splošna pomota glede njegovih objav o Cerkniškem jezeru, Slovenija}

Valvasor je svojo prvo, razmeroma preprosto razlago presihanja Cerkniškega jezera, objavljeno 1687, močno spremenil in zapletel v knjigi Die Ehre dess Hertzogthums Crain in članku v Acta Eruditorum, kar oboje je izšlo 1689. Sodobni avtorji, ki niso preverjali svojih virov, napačno navajajo, da gre za prevod članka iz 1687, namesto da bi opozorili na te velike spremembe in razlike v Valvasorjevih zamislih.

Ključne besede: kras, presihajoče jezero, zgodovina, Cerknica, J.W. Valvasor. 
A practice has grown up in the last 20 years of wrongly referring to two very different $17^{\text {th }}$ century papers by Valvasor on the intermittent lake of Cerkniško jezero as if their content was the same.

In an attempt to prevent further perpetration of this mistake, the present paper shows that the two Valvasor papers do in fact present his changing views on the causes of the rapid appearance and disappearance of the lake's water. It also demonstrates the danger of repeating statements from secondary sources without checking their correctness.

\section{VALVASOR'S PUBLICATIONS ON THE LAKE}

Valvasor's descriptions of the lake appear in three of his publications, each of them attempting to explain how it was that an extensive lake could become dry land in a relatively short time and vice versa.

The earliest of these publications was his paper read to the Royal Society in London in December 1687 and published in their Philosphical Transactions (Valvasor 1687). In this he put forward a relatively simple explanation which was basically correct but, as will be seen, by 1689 he had developed (and complicated) his theory by adding a series of siphons.

The basic explanation in the 1687 paper was as follows. Beneath the surface lake is an underground one with which it connects through holes in the bottom. There are also one or more subterranean lakes beneath the nearby Javorniki hill; these are at a slightly higher level than the lake itself and they have their own independent exit passages which, under normal circumstances, can drain away the water they receive from underground streams as fast as it comes in. When the lakes beneath Javorniki receive more than these exits can carry, their level rises and they overflow through other channels both into the Cerknica underground lake, which therefore floods up through holes in the bed of the surface lake, and also directly into the lake itself from caves such as Vranja jama and Suha dolica. When "the Water draws off faster than it comes in ... the Lake must sink" (Valvasor 1687, 423-424). Less than two pages of this 1687 paper are devoted to the theory and there is no diagram.

By 1689 Valvasor's theory had developed, becoming more complex and less correct. The basic idea of an underground lake beneath the Cerknica one and of others inside the hills remained the same as in 1687 but the flow from one lake to another, he now supposed, was not only through simple passages but also through at least six siphons. Both this explanation and the earlier one are discussed in some detail elsewhere (Shaw (1992, 98-100).

The later and more elaborate explanation appeared in two publications in 1689. The first of these and the best known is the one in his great work Die Ehre dess Hertzogthums Crain (Valvasor 1689a) in the German language. This probably appeared some time before November of that year, for a review of its first volume was printed in the November issue of Acta Eruditorum (Anon. 1689), mentioning the lake only very briefly but reproducing Valvasor's map of it. In the book itself (Valvasor $1689 \mathrm{a}, 1,688-695)$ the new explanation is given in great detail, keyed by letters and numbers to the diagrammatic section reproduced here as Fig. 1.

Also in 1689, in the December issue of Acta Eruditorum, there is a less well-known paper (Valvasor 1689b) containing (pp. 636-644) a slightly abbreviated Latin translation of the relevant text from Die Ehre ..., together with the same diagram. The nine pages devoted in this paper to the elaborated theory of 1689 compare with less than two pages on the previous explanation in the 1687 Royal Society paper. 


\section{THE RECENT ERROR}

It is clear that the 1689 paper is entirely different to the one of 1687, containing a changed theory of the lake's action, besides being significantly shorter overall and illustrated by a new diagram.

Unfortunately the standard book about Valvasor by Reisp $(1983,184,403)$ did not point out this important distinction:

The summary of his [Valvasor's] long report about the Cerknica lake

was already published in the December number of Philosophical Transactions, London 1687, Nr. 191, in English and after that also in Acta Eruditorum, Leipzig 1689 in the Latin language.

Indeed this seems to imply that the two publications were of the same paper in English and in Latin. In his bibliography (Reisp 1983, 337) the only Acta Eruditorum references he cites are for the reviews of Die Ehre... (Anon. 1689, etc.) and not the paper by Valvasor (1689b). Four years later (Reisp 1987, 100, 110) he removed any possible doubt by saying that the same report was published in Philosphical Transactions "and then in Latin in the Acta Eruditorum, Leipzig 1689, pp. 634-644." The same statement was repeated in an exhibition catalogue (Reisp 1989, 64, 101). He can never have examined the original papers he refers to.

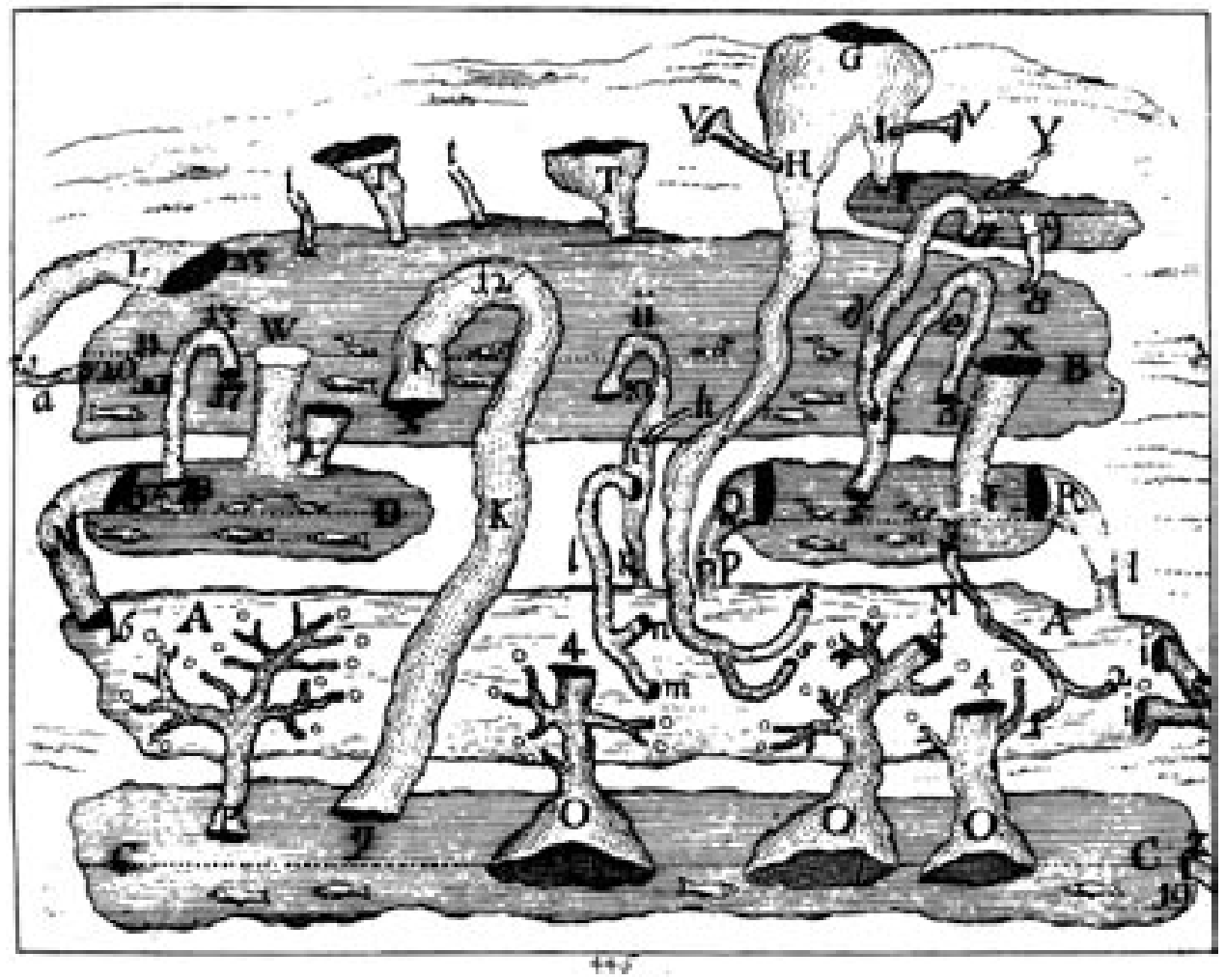

Fig. 1: Valvasor's diagram illustrating the action of underground lakes and siphons needed to supply Cerkniško jezero (AA) itself, according to his second (1689) theory. 
Subsequent authors have followed Reisp. By not verifying their sources they missed the opportunity of emphasizing the significant development in Valvasor's ideas between the 1687 paper and the one of 1689.

Most recently Južnič $(2002,214)$ has been misled into stating that the 1689 Latin paper was just a [translated] reprint of the 1687 English one:

Leipzig reprint ["ponatis"] of Valvasor's article that won his election

into the Royal Society.

Furthermore, he gave an impossible reference for the Leipzig version, combining the month of Anon. (1689) with the pages of Valvasor (1689b).

Valvasor is too important to karstology and for Slovenia to allow this error to be perpetuated further.

\section{REFERENCES}

Anon., 1689 : [Review of] Die Ehre des Hertzogthums Crajn aussgebreitet von Johann Weichart Valvasor Freiherrn ... Tomus I. - Acta Eruditorum (11) (Nov.), 549 - 559, Leipzig.

Južnič, S., 2002 : Treatises about the subterranean world in Ljubljana between 1678 and 1773. - ActaCarsologica 31 (2), 209-221, Ljubljana.

Reisp, B., 1983 : Kranjski polihistor Janez Vajkard Valvasor. - Mladinska kniga, p. 431, Ljubljana.

Reisp, B., 1987 : The correspondence of Janes Vajkard Valvasor with the Royal Society. - SAZU, p. 113, Ljubljana [Epistulae Slovenorum illustrium , 8].

Reisp, B., 1989 : J.V. Valvasor ... Katalog ... -Pp. 13-124 in Janez Vajkard Valvasor Slovencem in Evropi, Narodna Galerija, p.229, Ljubljana.

Shaw, T.R., 1992 : History of cave science the exploration and study of limestone Caves, to 1900 $-2^{\text {nd }}$ edn., Sydney Speleological Society, p. xiv, 338, Sydney (first published 1979 by Anne Oldham, Crymych, with Valvasor's theories about Cerkniško jezero on pp. 130-132.).

Valvasor, J.W., 1687 : An extract of a letter written to the Royal Society out of Carniola, being a full and accurate description of the wonderfull Lake of Zirknitz in that courtry. - Philosphical Transactions 16 (191), 411-426 [=427].

Valvasor, J.W., 1689a : Die Ehre dess Hertzogthums Crain... - Endter, 4 vols., Ljubljana.

Valvasor, J.W., 1689b : Lacus Cirknicensis potiora phaenomena ex principiis physicis \& mathematicis explanata. - Acta Eruditorum (12) (Dec.), 634-644, Leipzig. 